\title{
The International Law Commission and Change: Not Tracing but Facing It
}

\author{
Alejandro Rodiles
}

Turn and face the strange. ${ }^{1}$

\section{Introduction}

International law is undergoing profound transformations. This affirmation has become a commonplace nowadays, but as most commonplaces, it reflects reality. But then again, the reality underlying commonplaces tends to be more complex than what the latter is able to tell us on its own, and this complexity can only be grasped through differentiation. This is also the case when one tries to understand what international law's transformations are actually about. In an initial step, one has to differentiate between changes in and of international law. In the first case, we are in the presence of international law's contents and how they evolve over time. The second concerns the changing ways in which contents are made.

Changes in the law do not transform a legal system into something else, at least not from a formal, systemic point of view. Debates about the increasing juridification of international affairs are about changes in the law. As Hans Kelsen already observed, there are no fixed material boundaries to international law because it can deal with any subject-matter States agree to regulate on the international plane. ${ }^{2}$

The International Law Commission is a privileged witness of the genesis, transformation, and decay of international legal materials due to its place within the United Nations Organization, the assistance it receives from the United Nations Office of Legal Affairs, the institutionalized communication with States, especially through the channel of the General Assembly's Sixth Committee, ${ }^{3}$ the legitimacy it enjoys because of its multi-regional

1 David Bowie, 'Changes' in David Bowie, Hunky Dory (RCA 1971).

2 Hans Kelsen, Principles of International Law (Rinehart \& Company, Inc. 1952) 190-192.

3 Articles 16, 17 and 18 of the ILC statute, UNGA Res 174 (II) (21 November 1947), as amended by UNGa Res 485(v) (12 December 1950); UnGa Res 984(x) (3 December 1955); UnGA Res 985(x) (3 December 1955) and Unga Res 36/39 (18 November 1981). 
composition, ${ }^{4}$ as well as the balance between academic expertise and diplomatic experience. ${ }^{5}$ However, it is important to clarify that just as a prime witness contributes through her testimony to the construction of legal truth, so too is the Commission's work crucial in the identification, existence, and evolution of international law.

To summarize, when it comes to changes in the system, the Commission helps to make them visible in the beginning, already articulating the law-tobe, which is then used in the further positivization of the law. In a way, this is nothing but the old story of the codification and progressive development of international law, but explained by means of the idea of construction through re-construction. ${ }^{6}$ The added value of this explanation lies in that it helps to unpack the complex value-chains of international legal production, ${ }^{7}$ while it also highlights the vital role of change in the endurance of the system over time. The Commission is a key player in this kind of norm-production dynamics that have been able to achieve a delicate balance between stability and change, ${ }^{8}$ thus allowing for a successful evolution of international law, despite its decentralized architecture.

However, when changes of the system are concerned, the risk of destabilization is acute. Here, we are not in the presence of evolving contents, but of moving structures. Thus, the issue is not about international law dealing with the protection of the atmosphere ${ }^{9}$ or crimes against humanity, ${ }^{10}$ but about the ways in which these and other issues are dealt with. These changes entail the questions of whether the factory of international law

$4 \quad$ Ibid Article 8.

5 Christian Tomuschat, "The International Law Commission - An Outdated Institution" (2006) 49 GYIL 77.

6 This passage owes much to Wouter Werner, 'Restating Restatements: Repetition in the ILC Report on the Identification of Customary Law' (unpublished paper, on file with the author).

7 The ILC member Sean Murphy has previously resorted to the 'factory' metaphorical structure to describe the work of the Commission, see Sean D. Murphy, 'Codification, Progressive Development, or Scholarly Analysis? The Art of Packaging the ILC's Work Product' in Maurizio Ragazzi (ed), The Responsibility of International Organizations: Essays in Memory of Sir Ian Brownlie (Martinus Nijhoff 2013) 29.

The topic of "treaties over time", as initially proposed by Georg Nolte, is framed in precisely those terms in relation to treaties, see ILC, 'Report of the International Law Commission on the work of its sixtieth session' [2008] II(2) ILC Ybk 1, 365-384.

$9 \quad$ ILC, 'Report of the International Law Commission on the work of its seventieth session' (2018) UN Doc A/73/10, 157-200.

10 ILC, 'Report of the International Commission on the work of its Sixty-ninth Session' (2017) UN Doc A/72/10, 9-127. 
operates differently today, and whether the shifts in operation are transforming the factory into a site of variegated and innovative global norm production.

Whereas the role of the Commission regarding changes in the system is undisputed, its capacity to deal with changes of the international legal order cannot be taken for granted. One might even say that the same circumstances that make this organ so privileged in the former case are the ones which put its adaptive aptitude to changing structures under strain. Its place within the United Nations, its State-focused work and its rather formalistic working methods ${ }^{11}$ make us think of the Commission as quite an orthodox institution, ${ }^{12}$ which would resist rather than face change.

In this chapter, I argue that the perception of a deficient capacity of the Commission to cope with the changing structures of the international legal system is not accurate. ${ }^{13} \mathrm{~A}$ way of showing this is by recalling another 'crisis' that the Commission has faced in the past. An underlying preoccupation about the Commission's impact has been its decreasing role in the codification of international law. But the nostalgia about the Commission's "golden age", ${ }^{14}$ when it used to draft great codification projects that resulted in hallmark multilateral

11 See the contribution of Danae Azaria in Section 4 of this book.

12 In this sense, see Matthias Forteau, 'Comparative International Law Within, Not Against, International Law' in Anthea Roberts et al (eds.), Comparative International Law (oup 2018) 161 at 166; and Georg Nolte, 'The International Law Commission and Community Interests' in Eyal Benvenisti and Georg Nolte (eds), Community Interests Across International Law (OUP 2018) 101 at 117.

13 Understanding a set of norms in terms of a system means that those norms are not unconnected, but tied through a relationship. In other words, it means that explaining a set of norms plus a relationship (which can be very complex, indeed) is a mental representation of a legal order as a system that provides the criteria for the identification and unity of that order. It is, in this sense, that I use the notions 'legal order' and 'legal system' interchangeably. In doing this, I am highlighting the systemic understanding of the international legal order. On this, see Ricardo Caracciolo, 'Sistema Jurídico' in Ernesto Garzón Valdés and Francisco J. Laporta, El Derecho y la Justicia (Trotta, $2^{\text {nd }}$ edition, 200o) 161; id., 'Rechtsordnung, System und Voraussagen des Rechts' in Ernesto Garzón Valdés and Eugenio Bulygin, Argentinische Rechtstheorie und Rechtsphilosophie heute (Duncker \& Humboldt 1987) 117 .

14 This was very present in the ILC's sixtieth anniversary, and already during the fiftieth session; see ILC, 'Report of the International Law Commission on the work of its sixtieth session' [2008] II(2) ILC Ybk 1, 348-35o (referring to the commemoration of the sixtieth anniversary of the Commission and the following meeting with legal advisers of member states under the theme The International Law Commission: Sixty Years...And Now?); and the various contributions in The International Law Commission Fifty Years After: An Evaluation (United Nations 2000). 
treaties, some arguably even of "world order", ${ }^{15}$ actually reveals the adaptability of the Commission's work to changing circumstances. Commission members and others have mentioned this on the occasion of past anniversaries of the International Law Commission and elsewhere. ${ }^{16}$ While they acknowledged the fading scope of possible topics to be codified, given what the Commission had already covered by 1997 or 2007, they also asserted that this should not be regretted because there is still much to be clarified with regard to the basic rules of general international law. ${ }^{17}$

Indeed, what may be perceived as the vanishing importance of the Commission actually shows its resilience, i.e. the Commission's ability to cope with the changing structures of international law. As mentioned by Georg Nolte, there is a need to "reaffirm and continue developing the general rules of the game". 18 I would add that this continued requirement is driven today by moves that threaten to change the game altogether. Thus, this necessity is not only and not even primarily about elucidating the meaning and scope of legal concepts (such as permissible reservations and interpretive declarations to treaties), ${ }^{19}$ but about facing the means of production which seem to stem from a different site than the factory of international law.

In the following section, I will refer to these new normative products or "trends", to use Neil Walker's eloquent description. ${ }^{20}$ It is important to clarify, however, that I do not think that it is for the Commission to codify and progressively develop these trends. This is what I mean in alluding to the lyrics of David Bowie's 1971 "Changes": not tracing, but facing change. The way that these trends can be faced by the Commission may be described as the fine-tuning of the rules of the game so that these can respond to a changing and uncertain normative environment.

15 See Christian Tomuschat, 'Obligations Arising for States Without or Against Their Will' (1993) 241 RdC 269.

16 See Vaughan Lowe, 'Future Topics and Problems of the International Legislative Process Presentation by Vaughan Lowe' in The International Law Commission Fifty Years After: An Evaluation (United Nations 2000) 122-137; Christian Tomuschat, 'The International Law Commission - An Outdated Institution?' (2006) 49 GYIL 77; Georg Nolte, 'The International Law Commission Facing the Second Decade of the Twenty-First Century' in Ulrich Fastenrath et al (eds), From Bilateralism to Community Interests: Essays in Honour of Judge Bruno Simma (OUP 2011) 781 at 789-792.

17 Ibid.

18 Nolte (n 16) 792.

19 See ILC, 'Guide to practice on reservations to treaties' [2011] II(3) ILC Ybk 26-38.

20 Neil Walker, Intimations of Global Law (CUP 2015) 166-169. 
In the third section, I will show this fine-tuning by resorting to the work of the Commission on "Fragmentation of international law: difficulties arising from the diversification and expansion of international law", ${ }^{21}$ and to the conclusions on subsequent agreements and practice in relation to interpretation of treaties. ${ }^{22}$ While the former represents a watershed in the Commission's work, facing for the first time and comprehensively the structural transformations of international law, the latter provides endogenous means from the law of treaties to cope with trends that cannot easily be accommodated within the usual means of international law production.

In the fourth and concluding section, I will come back to the notion of the Commission's and international law's resilience. It will then become clear, I hope, that this resilience is not about grasping at straws, nor an academic obsession with international law's purity, but a rather fundamental struggle for the political ideas that inform the rule of law at the international level.

\section{A Bit on 'Trend-spotting'}

International legal scholarship has been dealing with international law's profound transformations for quite some time now, approaching them through different lenses. Writings on global administrative law (GAL), ${ }^{23}$ informal international law-making (IN-Law), ${ }^{24}$ the interplay between formality and informality, ${ }^{25}$ transnational legal orders, ${ }^{26}$ the decay of State consent, ${ }^{27}$ global legal pluralism, ${ }^{28}$

21 ILC, 'Fragmentation of international law: difficulties arising from the diversification and expansion of International Law' [2006] II (2) ILC Ybk 175; see also 'Fragmentation of international law: difficulties arising from the diversification and expansion of international law - Report of the Study Group of the International Law Commission' (2006) UN Doc A/ CN.4/L.682 (hereinafter, "Report of the Study Group on Fragmentation").

22 ILC (n 9) 11-116.

23 See Benedict Kingsbury, Nico Krisch and Richard B. Stewart, 'The Emergence of Global Administrative Law' (2005) 68 Law\&ContempProbs 15.

24 See Joost Pauwelyn et al (eds), Informal International Lawmaking (OuP 2012).

25 See Alejandro Rodiles, Coalitions of the Willing and International Law - The Interplay between Formality and Informality (CUP 2018).

26 See Terence C. Halliday and Gregory Shaffer (eds), Transnational Legal Orders (CUP 2015).

27 See Nico Krisch, 'The Decay of Consent: International Law in an Age of Global Public Goods' (2014) 108 AJIL 1.

28 See Paul Schiff Berman, Global Legal Pluralism - A Jurisprudence of Law Beyond Borders (CUP 2012). 
and global law more broadly, ${ }^{29}$ are all motivated by the growing perception among scholars of the changing structures of international law. Even the question retaken by Anthea Roberts of whether international law is international, and the broader comparative international law project of which Roberts' book is a part, ${ }^{30}$ are closely interlinked with the issue of the structural transformations of the international legal order. In the end, an emphasis on observing and acknowledging how international law functions differently in different places cannot but affect the classical post-war conception (or aspiration) of international law qua universal legal system. ${ }^{31}$

The possible objection, consisting in that these approaches and observations are of a predominantly academic nature, should be addressed here. This is so since the Commission is, for very good reasons, perceived as a practice-oriented body and not an academic institution. But these observations are made with regard to new practices of what is going on out there when States, alone or in concert with other actors, address climate change, migration, or international security issues like terrorism, piracy, weapons of mass destruction, or cyber attacks. As I have argued elsewhere, ${ }^{32}$ it would be quite anachronistic to teach today a course on the law of the sea without engaging with coalitions of the willing like the Proliferation Security Initiative (PSI), or on international environmental law without paying due regard to the several players (from the private sector to cities) involved in "the transnational regime complex for climate change". ${ }^{33}$ So, it would be problematic, if not selfdefeating, for international lawyers, including for the Commission, to ignore these trends.

The normative products that result from the new practices are manifold and do not easily fit within the classical sources of international law, ${ }^{34}$ i.e. with those principles and rules identified in the Statute of the International Court of Justice. ${ }^{35}$ Best practices, indicators, standards, recommendations, and

29 See Anne-Marie Slaughter, 'Filling Power Vacuums in the New Global Legal Order' (2013) 54 BCLRev 919; for a comprehensive and distanced analysis, see Walker (n 2o).

30 See Anthea Roberts, Is International Law International? (Oup 2017); Anthea Roberts et al (eds) (n 12). The importance of this question was previously emphasized by Martti Koskenniemi, 'The Case for Comparative International Law' (2009) 20 FinnishYBIL 1.

31 See also Forteau (n 12).

32 See Rodiles (n 25) p. $25^{2}$.

33 Kenneth Abbott, 'Strengthening the transnational regime complex for climate change' (2014) 3 Transnational Environmental Law 57.

34 See Benedict Kingsbury, 'The Concept of 'Law' in Global Administrative Law' (2009) 20 EJIL 23 .

See Article 38 of the Statute of the International Court of Justice. 
pledges are the types of global normative trends most commonly known, but this list is only indicative of the burgeoning tendency to regulate and coordinate behavior through unorthodox ruling devices. What these products have in common is that they are non-legally binding. But it is important to underline that they are not just policies. No matter how much those products claim not to produce legal obligations, they are at least directing behaviour in the global realm. More often than usually acknowledged, they are attached to legal norms and processes in an intense and mutually defining interplay. ${ }^{36}$

It is true that a crucial factor spurring these normative trends is the prominent role of non-state actors in the various fields of global governance. Just think of the impact of the self-regulatory practices of Facebook, Google, and Twitter on content moderation, ${ }^{37}$ internet governance more broadly, and what all of this actually means for public law issues on the global scale, like freedom of expression, data protection, security, and democracy indeed. ${ }^{38}$ Subnational entities, mostly cities, are today undisputable global actors on topics such as climate change, security, and human rights, and their role in the most ambitious United Nations programme, i.e., the 203 o Sustainable Development Agenda, ${ }^{39}$ is literally ubiquitous, going clearly beyond Sustainable Development Goal 11 which expressly deals with safe, resilient, and sustainable cities. ${ }^{40}$ These evolutions have led one to posit the question on the possible character of cities as new (old) subjects of international law, ${ }^{41}$ a question that has been taken up as one of the objectives of the new study group on "The role of cities in international law" of the International Law Association (ILA). ${ }^{42}$

Given that the Commission is a creature of the United Nations General Assembly and that its main audience is that of United Nations Member States, one may be inclined to think that the Commission is not the proper organ to assess what these other global actors do. That is already a problematic assumption in itself. However, the bigger problem is to think that the conduct

$36 \quad$ See Rodiles (n 25).

37 See, for instance, Facebook Community Standards, <https://www.facebook.com/communitystandards//> (as of 18 February 2019).

38 See Eyal Benvenisti, 'EJIL Foreword: Upholding Democracy Amid the Challenges of New Technology: What Role for the Law of Global Governance' (2018) 29 EJIL 9.

39 UNGA Res 70/1 (21 October 2015).

40 See the various contributions in Helmut Philipp Aust and Anél du Plessis (eds), The Globalisation of Urban Governance - Legal Perspectives on Sustainable Development Goal 11 (Routledge 2019).

41 Particularly illustrative on this, see Helmut Philipp Aust, Das Recht der globalen Stadt (Mohr Siebeck 2017), 141-194.

42 See $<$ http://www.ila-hq.org/index.php/study-groups >. 
of States does not contribute to the new normative trends, or, in other words, that the structural changes of international law are solely spurred by non-state actors and subnational entities. States are themselves behaving in unorthodox ways when it comes to global action and regulation. There is now a well-settled inclination of these traditional subjects of international law to gather in informal coalitions of the willing and to coordinate actions and decision-making through networks, often circumventing classical international organizations, and law-making. ${ }^{43}$ These alternative forms of cooperation frequently serve to shape the work of intergovernmental organizations, through orchestration tactics performed by a few member States of the latter that participate in the former. ${ }^{44}$ 'Participating States parties' is an emerging category of this interplay between informal coalitions and formal international organizations. Note, for instance, the case in which participating States to a coalition agree to provisionally apply amendments to a treaty of which they are parties, and which have not entered into force. ${ }^{45}$ It is difficult not to think here of the current work of the Commission on provisional application of treaties, led by the Special Rapporteur Juan Manuel Gómez Robledo, ${ }^{46}$ and of the utility of fine-tuning article 25 of the Vienna Convention on the Law of Treaties ${ }^{47}$ vis-à-vis these evolutions.

The interplay between formality and informality that States entertain also affects the evolution of other international legal obligations like United Nations Security Council resolutions. The design and implementation of the United Nations sanctions today cannot be understood without studying what States do, not only in the Security Council and within their national jurisdictions, but also as participants in a selective club like the Financial Action Task Force. ${ }^{48}$ This interplay eventually leads to a contemporary reading of traditional concepts of treaty law, especially subsequent practice and agreements, in their recognized mutatis mutandis application to Security Council resolutions. ${ }^{49}$

\footnotetext{
43 See Rodiles (n 25).

44 Ibid 202-209.

45 This has been the case, e.g., of the participating States of the Nuclear Security Summit which are parties to the Convention on Physical Protection of Nuclear Material, see ibid 192-193.

46 ILC (n 9) 2O1-223.

47 Vienna Convention on the Law of Treaties, adopted 23 May 1969, entered into force 27 January 1980, 1155 UNTS 331.

48 See Alejandro Rodiles, 'The Design of UN Sanctions through the Interplay with Informal Arrangements' in Larissa van den Herik (ed), Research Handbook on UN Sanctions and International Law (Edward Elgar 2017) 177-193.
}

49 See Accordance with International Law of the Unilateral Declaration of Independence in Respect of Kosovo (Advisory Opinion) [2010] ICJ Rep 403; see also Michael Wood, 'The 
The above-mentioned examples are but a snapshot of the many new global normative trends. These examples show, nonetheless, why international lawyers need to - and do - engage in "trend-spotting"50 more and more often, borrowing again from Neil Walker. In the ensuing pages, I will argue that today the Commission may have one of its most important impacts by explaining the new normative global trends from within the international legal system. This means that these normative trends, however at odds they may are with classical international law, its doctrine of sources, and its formal rationality indeed, have to be taken very seriously by the people and institutions that devote their work to international law as we know it.

In my view, however, it is not the task of the Commission to identify such new normative trends in the sense of declaring whether certain informal norms should be considered as part of international law (whether there is something as IN-law, ${ }^{51}$ for instance), thus broadening the sources and the concept of international law. This would push the Commission to its institutional limits and put its legitimacy in jeopardy.

The Commission cannot afford to ignore new and unorthodox normative trends if it wants to retain its relevance in the contemporary global legal landscape. However, it is not the Commission's custom to explicitly address these trends in the sense of codifying and progressively develop them; nor should this be the case. Instead, the way of dealing with new, alien products consists in the identification, explanation, and elaboration of the existing tools of the system, which will then help to assess these extra-systemic normative devices as they operate in connection with international law.

Analytically, this means that the kind of work of the Commission that is most likely to unfold a significant impact today is the one that is systemic in nature, concerning secondary and not primary rules. From the point of view of the Commission's professional ethic, this requires a self-comprehension that is conscious of its institutional constraints, respectful of its historical purpose, while being increasingly sensitive to context. In this section, I will refer to the

Interpretation of Security Council Resolutions' (1998) 2 MaxPlanckUNYB 73; see also Michael Wood, 'The Interpretation of Security Council Resolutions, Revisited' (2017) 20 MaxPlanckUNYB Online 1.

50 Walker (n 20) 159-161.

$5^{1} \quad$ See Pauwelyn et al ( $\mathrm{n}$ 24). 
role of the Commission in elaborating on "the general rules of the game"52 in the face of big transformations. Since the professional ethic of the Commission is strictly related to the struggle for the international rule of law, I will return to it in the concluding remarks.

The work of the Study Group on the "Fragmentation of international law" constitutes a watershed in the work of the Commission, which faced for the first time straightforwardly international law's structural transformations and signalled to a great extent the way ahead. It is true that its focus on the diversification of international legal regimes and the collision and harmonization of norms from within international law represent, prima facie, an analysis of major changes in the system - provided that the different fields of international law are part of a single and unified legal order, which was a major question back in the beginning of the millennium when the Commission decided to include the topic "risks ensuing from fragmentation of international law" on its long-term programme of work, based on the feasibility and already very illustrative study presented by Gerhard Hafner. ${ }^{53}$

Nonetheless, in dealing explicitly with the systemic question par excellence, namely with the nature of "international law as a legal system", 54 it sets the basis for understanding the interactions within and across normative complexes. Such complexes involve not only recognized legal regimes but also flexible, emerging and informal frameworks, i.e. the new global regulatory trends that present the most serious challenge to the coherence of the international legal order. This becomes clear in the report of the Study Group finalized by Martti Koskenniemi:

A discussion of the extent to which new types of "global law" might be emerging outside the scope of traditional, State-centric international law would require a different type of exercise. This is not to say, however, that the Vienna Convention or indeed international law could not be used so as to channel and control these patterns of informal, often private interest-drawn types of regulation as well. The more complex and flexible the ways in which treaty law allows the use of framework treaties, of clusters of treaties and regimes consisting of many types of normative materials, the more such decentralized, private regulation may be grasped within the scope of international law. ${ }^{55}$

$5^{2} \quad$ See Nolte (n 16) 792.

53 ILC, 'Report on the Work of its Fifty-Second Session' [2000] II (2) ILC Ybk 2.

54 See the Conclusions of the work of the Study Group (n 21) 177-178.

55 See Report of the Study Group on Fragmentation (n 21) 248. 
This paragraph reflects the need for international lawyers to engage with normative trends from outside the system, "the new types of 'global law', which may derive from private actors, public-private partnerships, "or other types of informal regulation of transnational activities",56 like the trends discussed in the previous section of this chapter. The request to take these trends seriously is addressed to the Commission itself, since it figures in the section on "The perspective of this Study",57 which is framed as suggestions for the Commission to deal with "[t]he whole complex of inter-regime relations [which] is presently a legal black hole".58 Importantly, it makes clear that this engagement should not be a sort of trend-spotting. Instead, it should be about applying the existing tools of international law (i.e. the 1969 Vienna Convention on the Law of Treaties and general international law) to these trends in order to understand "their effects on traditional law-making".59

In light of the context of the section in which this paragraph figures and of the whole report indeed, it also becomes clear that the need to face these trends is most acute in regard to the interactions they entertain with traditional international law, public and private, within and across international and transnational regime complexes. This reflects, in my view, an early warning of the risks that result from the enmeshment of traditional and non-traditional normative clusters. Such enmeshment jeopardizes the coherence and certainty aspirations of international law qua legal system. As Koskenniemi developed in his academic writings on the deformalization of international law, such a development undermines the idea that the "world can - or should - be governed through a single international law". ${ }^{60}$

According to the Study Group's report, the tools of international law which serve to understand and ultimately "channel and control these patterns of informal $[\ldots]$ regulation" 61 are secondary rules, coming mainly from the law of treaties as well as from general international law. In this sense, it can be said that this report picks up and builds upon the calls that were made on the occasion of the fiftieth and sixtieth anniversaries of the Commission, which were quite clear on the need to concentrate on the systemic components of international law, i.e. on the "general rules of the game". ${ }^{62}$ The report finalized

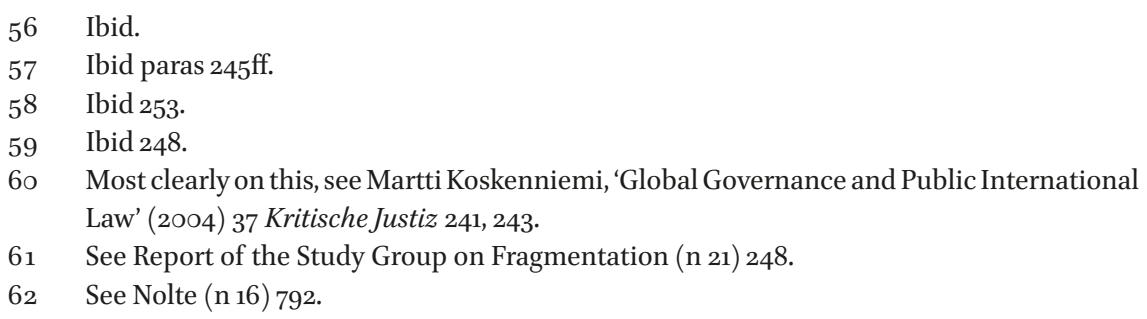


by Koskenniemi makes no bones out of this: "there is a limit to what can be obtained in terms of codification and progressive development of universal rules".63

Given the object of this study, the specific norms that are commented and elaborated on are collision rules as those known from private international law. Actually, one of the main proposals is to understand and use the Vienna Convention on the Law of Treaties "as a basis of an 'international law of conflicts' ". ${ }^{4}$ Similarly, those 'general principles as recognized by civilized nations' that are drawn upon, i.e. lex specialis, lex prior, lex posterior, ${ }^{65}$ serve the main function of overcoming collisions of rules that stem from the different and increasingly specialized fields of international law.

It must be clarified that contrary to the articles on the responsibility of States for internationally wrongful acts, ${ }^{66}$ which identify, develop, and systematize secondary rules on attribution, legal consequences, exceptions, invocation, etc., the Report of the Study Group on Fragmentation does not codify and progressively develop, but comments and elaborates on already well-established secondary rules of change, ${ }^{67}$ like those on interpretation of, derogation from, and suspension of rules of international law. Hence, the report of the Fragmentation Study Group suggests to the Commission a turn to restatements of international law:

Thus, it is proposed that the Commission should increasingly look for the avenue of "restatement" of general international law in forms other than codification and progressive development - not as a substitute but as supplement to the latter. ${ }^{68}$

63 See Report of the Study Group on Fragmentation (n 21) 256.

64 Ibid 25o. Here, the influence of Gunther Teubner and Andreas Fischer-Lescano is quite clear; see Andreas Fischer-Lescano and Gunther Teubner, Regime-Kollisionen (Suhrkamp 2006).

65 These principles are derived from the medieval glossae of the Code of Justinian made by the Bologna school in the twelfth and thirteenth centuries. Back then, they already served as collision-rules in a highly pluralistic legal environment. They have become part of the general principles of several national legal systems across the globe, especially in those influenced by the Roman-German-Canonical legal tradition; see Harold J. Berman, Law and Revolution: The Formation of the Western Legal Tradition (Harvard University Press, 1983); see also Rolando Tamayo Y Salmorán, La Ciencia del Derecho y la Formación del Ideal Político (UnAm 1989).

66 ILC, 'Draft articles on responsibility of States for internationally wrongful acts' [2001] II(2) ILC Ybk 26.

67 See H.L.A. Hart, The Concept of Law (Clarendon Press/OUP 1994) 95-96.

68 See Report of the Study Group on Fragmentation (n 21) 256. 
Since then, it can fairly be said that repetition and explanation have become recurrent activities of the Commission, ${ }^{69}$ such as the completed work on subsequent agreements and subsequent practice in relation to the interpretation of treaties ${ }^{70}$ and the identification of customary international law, ${ }^{71}$ and the ongoing study on provisional application of treaties ${ }^{72}$ demonstrate. This tendency is quite inevitable, and contrary to what some may think, it is well-suited for dealing with a changing normative environment.

Indeed, a good example of a recent Commission's restatement that faces structural changes in the way outlined in the report of the Study Group on fragmentation is the work on subsequent practice and agreements. The conclusions on this topic and their commentaries can help explain much of what is going on out there in terms of normative evolutions that are not strictly part of classical international law, but that are tied to international legal materials, especially treaties (bilateral and multilateral), and other normative instruments such as United Nations Security Council resolutions. ${ }^{73}$

Let us take, for instance, the proliferation of 'best practices', as identified and developed by, inter alia, expert treaty bodies in relation to the implementation of treaties, and how these informal norms, as well as other trends, like typologies and indicators, can spur the practice of States parties in the application of a treaty norm. The potentially relevant role of the former in treaty interpretation is something which becomes much clearer in light of the Commission's clarification and contextualization of the meaning and scope of article 31, paragraph 3 (b) of the Vienna Convention on the Law of Treaties. To be clear, the technocratic trend in the management of multilateral treaties through best practices and other informal norms is not spotted by the Commission in the conclusions of this topic. The latter constrain themselves to identifying, recalling, and fine-tuning the tools offered by positive international law in order to face the new trends of treaty-management from within the law of treaties. Thus, we are not in presence of a sort of surrender to "expert rule", ${ }^{74}$ quite to the contrary: the work of the Commission on

69 In this sense, although grounding it on different theoretical frameworks and taking different positions, see: Matthias Forteau, 'Comparative International Law Within, Not Against, International Law' in Anthea Roberts (n 12) 161 at 166; and Werner (n 6).

$70 \quad$ ILC (n 9) 11-116.

$71 \quad$ ILC (n 9) $117-156$.

72 ILC (n 9) 201-223.

73 See $\mathrm{n} 49$ and accompanying text.

74 David Kennedy, 'Challenging Expert Rule: The Politics of Global Governance' (2005) 27 SydneyLR 1 . 
subsequent agreements and practice can be described as making clear(er) what the legal conditions are for best practices, indicators, and typologies to become relevant in the interpretation of treaties and their evolution over time. The agreement, i.e. the common understanding of the parties to the treaty, concerning the normative content that may or may not result from the practice in its application, is unambiguously emphasized in draft conclusion 10 as a sine qua non condition for any authentic interpretation to arise. ${ }^{75} \mathrm{In}$ case this condition of a common understanding regarding the interpretation is not met, the practice based on these non-binding trends may still play a role, but only as a subsidiary means of interpretation according to article 32 Vienna Convention of the Law of Treaties (draft conclusion 4.3) ${ }^{76}$ Best practices and the like may not necessarily spur future developments, but they can also serve an evidentiary role regarding existing subsequent practice ("assessing such practices", ${ }^{77}$ in the words of the Commission). The commentaries to the conclusions elucidate this possible role of guidelines or handbooks of international organizations and agencies. ${ }^{78}$

Laurence Boisson de Chauzournes argues that best practices and other "major trends" form part of what she calls "family practices", that is the kinds and species of conduct, traditional and non-traditional, State-centred or not, that "have legal relevance under today's treaties". ${ }^{79}$ Understanding how those practices function and become relevant for the life of treaties, i.e., for their interpretation, application, and evolution, requires the sort of 'contextual sensitivity' highlighted in the report of the Study Group on fragmentation, ${ }^{80}$ which in this case "embeds subsequent practice in its proximate operative milieu". 81 Thereby, the wide-open texture of the concept of 'practice' in international law is also acknowledged. Accordingly, there is a complex interplay among many species of practices that relate to a given treaty norm, and that can only be ignored at the peril of reducing the role of subsequent practice as a means of interpretation to its minimalist expression, something which could have very little to do, in the end, with the actual meaning, scope, and efficacy of the treaty norm. Such a minimalist version would waste the great potential of the rules

\footnotetext{
$75 \quad$ ILC (n 9) $75^{-77}$.

76 Ibid 33 .

77 Ibid 40 .

78 Ibid 40-41.

79 Laurence Boisson de Chazournes, “"Subsequent Practice”, and "Family-Resemblance”: Towards Embedding Subsequent Practice in its Operative Milieu' in Georg Nolte (ed), Treaties and Subsequent Practice (OUP 2013) 53, 55 and 62.

8o See Report of the Study Group on Fragmentation (n 21) 248-250.

81 See Boisson de Chazournes (n 79) 62.
} 
of the Vienna Convention on the Law of Treaties to comprehend increasingly complex treaty regimes. ${ }^{82}$

The restatements of the Commission, like that on subsequent agreements and practice, remind us and clarify the potential of existing rules, fulfilling thus also an important pedagogical function in regard to the confusions caused by the shifting normative environment. ${ }^{83}$ This pedagogical function is widely accepted because of the legitimacy that the Commission enjoys. However, it should not be overstretched. Actually, its strength also resides in recognizing that in certain cases it can only provide the legal frames of reference for ongoing debates about unclear normative developments. The Paris Agreement on Climate Change may serve to explain this. ${ }^{84}$ The innovative architecture of this treaty, which imported several governance techniques, ${ }^{85}$ has become a puzzle for international lawyers in many respects. Suffice it here to briefly refer to the national determined contributions (NDC s). Scholars have classified them as unilateral declarations, ${ }^{86}$ but their non-binding nature makes this rather doubtful. More convincing is the attempt to explain them as a potential case of subsequent practice. ${ }^{87}$ Indeed, every party is to communicate in its NDC how it intends to apply the treaty. The problem is that the common understanding which is required to emerge from such eventual practice, as expressed in the words the "agreement of the parties regarding its interpretation" in article 31, paragraph 3(a) of the Vienna Convention on the Law of Treaties, is extremely unlikely to arise through this highly decentralized implementation design. ${ }^{88}$

In my view, the Paris Agreement is designed to foreclose any common understanding regarding its interpretation, precisely because that is part of the quo for having a nominally legal instrument. If my argument is correct, it shows that subsequent practice cannot be restated so as to explain what is not

82 Seealso Nele Matz-Lück, 'Norm Interpretation Across International Regimes:Competences and Legitimacy' in Margaret A. Young (ed), Regime Interaction in International Law: Facing Fragmentation (CUP 2012) 201-234.

83 On this "educational function" of restatements, see also Werner (n 6).

84 Paris Agreement, adopted 12 December 2015, entered into force 4 November 2016, UNTS registration no 54113 .

85 See, e.g., Charles F. Sabel and David G. Victor, 'Making the Paris Process more Effective: A New Approach to Policy Coordination on Global Climate Change', Policy Analysis Brief (The Stanley Foundation, February 2016).

86 See Jorge E. Viñuales, 'The Paris Agreement: An Initial Examination (Part II of III)' (EJIL: Talk!, 8 February 2016) <https://www.ejiltalk.org/the-paris-climate-agreement-an-initialexamination-part-ii-of-iii/>.

87 See Annalisa Savaresi, 'The Paris Agreement: A Rejoinder' (EJIL: Talk!, 16 February 2016) <https://www.ejiltalk.org/the-paris-agreement-a-rejoinder/>. 
within the reach of article 31, paragraph 3 (b) of the Vienna Convention on the Law of Treaties, and, in doing this, it also shows that the NDC s remain a puzzle for the law of treaties as we know it. But as my argument is but an argument, it also illustrates, that the restatement performed by the Commission recasts the attention to a very useful frame of reference, enabling it to function "as part of an ongoing, future-oriented discussion" ${ }^{89}$

\section{Conclusion}

The current and future impact of the Commission should be assessed in light of the structural transformations that international law as a legal system is going through, i.e. the changes of, not in, the system. The challenge for the Commission should not be underestimated: if it wants to retain a meaningful role, it has to face these changes. Ignoring them comes at the peril of shrinking its significance and influence concerning the manifold ways the world is being ruled today. At the same time, however, the Commission is not well-suited for adventures. Being a fundamental institution of the system, its strength lies in the privileged position it has within that system, the knowledge it has acquired of its sources and institutions, the assistance it receives from the United Nations Office of Legal Affairs, and the mixture of scholarly expertise, regional representation, and diplomatic experience that exists nowhere else. An essential component of this strength is the legitimacy that the Commission enjoys, precisely because it is a key part of the system. The Commission has to remain faithful to its principal audience, and the expectations that States place in it, the most important one arguably being the defence of the classical post-war international legal system, which it has helped to build over seven decades.

But this defence should not be understood as being for the sake of this legal order's integrity only. There are very strong meta-systemic reasons for defending international law as a legal system, reasons which are based on the political ideas that inform the rule of law at the international level. These have to do with the control of sheer power, the containment, to some extent, of asymmetries in international relations, and the construction of possibilities for the less powerful to articulate their views and demands. The new global normative trends challenge the conception of international law as a legal system, because they are not easily, if at all, traceable to a valid a source of law, and they are not usually, if ever, made according to the means (i.e. formal processes) that international law recognizes

89 Werner (n 6). 
with the "authoritative mark" that unifies the international legal system. ${ }^{90}$ If one translates these challenges for the systemic understanding of international law into threats to the political ideal of the international rule of law, it means, quite simply, that the new ruling devices of global governance are not transparent: it is not always clear who makes them; they foreclose predictability, since they do not claim to impose legal obligations but are highly efficient ruling devices; and they do not aspire to equal participation, because they circumvent State consent through international clubs, transnational networks, and global coalitions. ${ }^{91}$

That is, in my view, the reason why the report of the Study Group on Fragmentation is clear about the need "to channel and control these patterns of informal [...] regulation".92 The International Law Commission faces the dilemma of finding ways of ensuring that its work retains a meaningful impact in the complex global environment of fragmentation, governance, and informality, while remaining faithful to its mandate, expertise, and the expectations placed on it by the international community; expectations which come quite close to a conception of the Commission as "the priesthood of international legal formalism".93

Matthias Forteau's careful argument in relation to the role of the Commission with regard to the project on comparative international law (CIL) is revealing. ${ }^{94} \mathrm{CIL}$ can be explained as a major project aimed at studying the similarities and differences in the ways that international law is approached and functions in different places. ${ }^{95}$ It postulates that this, in principle, universal body of law may actually be about many particular versions of it. In a way, the project is another global normative trend since it takes the premise seriously that in an increasingly complex world characterized by non-polarity and a highly unstable political environment, international law is more prone to diversity than ever before. For Forteau, in the end, the Commission's work is a case in point for how developments that are not easily captured, conceptually

$90 \quad$ See Hart (n 67) 95.

91 On the meta-systemic value of the conception of the international legal system, see also Eyal Benvenisti, 'The Conception of International Law as a Legal System' (2007) 50 GYIL 393.

92 See Report of the Study Group on Fragmentation, (n 21) 248.

93 Forteau (n 12) 166 (quoting Kristen David Adams, 'Blaming the Mirror: The Restatement and the Common Law' (2007) 40 Indiana LR 205, 244, who describes in this vein the American Law Institute's Restatements on US law; Forteau says that the same can be said of the ILC's work in relation to international law).

94 Ibid.

95 Anthea Roberts et al, 'Conceptualizing Comparative International Law' in Anthea Roberts et al (eds) (n 12) 3-31. 
and operationally, as part of classical international law, may nonetheless be addressed - and resorted to - from "within international law (thus avoiding undermining it) in the process of establishing what international is or should be" ${ }^{\prime 6}$ The diplomatic sensitivities of the Commission and the support provided to it by the United Nations Secretariat makes the former particularly attentive to the many State practices, the identification of similarities and differences, and the careful conclusions that can be drawn from this convergence in diversity in terms of the status of international law on any given issue area. Accordingly, the Commission has learned to use "'accommodating' tools which permit common agreement on the drafting of an international rule while simultaneously preserving diversity". ${ }^{97}$ This explains, for instance, the resort to more flexible normative outcomes of the Commission, ${ }^{98}$ which are hence not to be viewed as a sign of its weakness (the lament of the glorious past expressed in the grand codification projects), but as a show of the skills it has developed in order to cope with drastic change.

One of the most efficient means for the Commission to face these changes from within the system is by resorting to restatements of the law, in particular of secondary, that is systemic, rules..$^{99}$ The report of the Study Group on fragmentation quite explicitly signals this working method as the way ahead,100 and recent outcomes of the Commission's work confirm this tendency.

In particular, the conclusions on subsequent agreements and practice and their commentaries show that it is possible to analytically and normatively intervene in the interstices where international legal and global non-legal materials converge by exclusively relying on the existing tools of the system, the rules of the game. The Report of the Study Group on Fragmentation paved this way by making visible the built-in-flexibility of international law as a resilient system, capable of coping with external stress without renouncing its essential qualities and "relative autonomy". ${ }^{101}$ One can expect that the major impact of the International Law Commission on the contemporary global legal landscape will increasingly consist in unravelling these capabilities to "turn and face the strange."102

\footnotetext{
$96 \quad$ Forteau, (n 12) 164 .

$97 \quad$ Ibid 173.

98 See the contribution of Laurence Boisson de Chazournes in this Section.

99 Forteau also talks about the ILC's contemporary work in terms of restatements, see Forteau (n 12).

100 See Report of the Study Group on Fragmentation (n 21) 256.

101 Jan Klabbers 'The Relative Autonomy of International Law or the Forgotten Politics of Interdisciplinarity' (2004 - 2005) 1 JIntlLIntlRel 35 .

102 Bowie (n 1$)$.
} 